\title{
An Update of the Brazilian Regulatory Bioequivalence Recommendations for Approval of Generic Topical Dermatological Drug Products
}

\author{
Kelen Carine Costa Soares, ${ }^{1,2}$ Gustavo Mendes Lima Santos, ${ }^{1}$ Guilherme M. Gelfuso, ${ }^{2}$ and Tais Gratieri ${ }^{2,3}$
}

Received 21 May 2015; accepted 15 June 2015; published online 27 June 2015

\begin{abstract}
This note aims to clarify the Brazilian regulatory bioequivalence recommendations for approval of generic topical dermatological drug products, since the legal framework of the "Brazilian Health Surveillance Agency" (ANVISA) is only available in Portuguese. According to Resolutions RE n. 1170 (December 19th 2006) and RDC n. 37 (August 3rd 2011) in Brazil, only in vitro studies are required for registration of generic topical dermatological drug products. Current Regulatory Agenda of ANVISA, which contains possible future resolutions to be revised over 2015-2016, includes a discussion on biowaiver requirements and on possible in vitro and in vivo comparability tests for these products.
\end{abstract}

KEY WORDS: bioequivalence; generic; topic.

In this note, we would like to comment a recently published review article on the similarities and differences among some international jurisdictions in accepting bioequivalence approaches for generic topical dermatological drug products [1]. The aims are to clarify the current requirements of the Brazilian Health Surveillance Agency (ANVISA) for registration of these products and to present the updated guidelines. Some language misinterpretations may have occurred, since the legal framework of the Brazilian Health Surveillance Agency (ANVISA) is only available in Portuguese.

The Brazilian guide cited in Table I of Braddy and coworkers' paper, relative to bioavailability/bioequivalence tests for dermatological topical drug products [1], has been replaced by the Resolution RE n. 1170 (December 19th 2006), which is still the currently valid document [2]. The current guideline describes how pharmacokinetics tests should be performed for those medicines requiring a demonstration of blood level bioequivalence and, in cases where it is not possible to precisely and accurately quantify the drug in circulation, when pharmacodynamic measurements may be accepted. Resolution RE n. 1170 does not provide guidance on how to conduct pharmacodynamic studies for topical formulations.

In spite of the mention of such pharmacodynamic tests, they are not required for topical dermatological drug product approval, as suggested in Tables II and III of the aforementioned review. Actually, bioequivalence studies with

\footnotetext{
${ }^{1}$ Coordination of Therapeutic Equivalence, General Office of Medicines, Brazilian Health Surveillance Agency (ANVISA), Brasília, DF, Brazil.

${ }^{2}$ Laboratory of Food, Drugs and Cosmetics (LTMAC), School of Health Sciences, University of Brasília (UnB), Brasília, DF, Brazil.

${ }^{3}$ To whom correspondence should be addressed. (e-mail: tgratieri@gmail.com)
}

pharmacodynamic endpoints are not required for any topical dosage form. According to the Resolution RDC n. 37 (August 3rd 2011), topical medicines, i.e., those not intended for systemic effects, are granted a biowaiver if the generic product contains the same active ingredient, in the same concentration as that of the reference product (pharmaceutical equivalents), and the generic product contains excipients that the same function as those of the reference formulation [3]. Therefore, only in vitro studies are required for registration of all generic topical dermatological drug products, including those containing corticosteroids. Such in vitro tests are described in either the Brazilian Pharmacopeia or in other official compendia acknowledged by ANVISA. Consideration for equivalence includes formulation general aspect, $\mathrm{pH}$, viscosity, density, drug active concentration assay, and microbiological tests results [4].

Current Regulatory Agenda of ANVISA, which contains possible future resolutions to be revised over 2015-2016, includes a discussion on biowaiver requirements and on possible in vitro and in vivo comparability tests for these products [5]. Nonetheless, only the post-approval guidance RDC48, of October 6th 2009, has mentioned the need to assess the drug permeability of topical dermatological products, although this guidance has not specified the experimental procedures to be followed [6].

In revision process of Resolution 1170, ANVISA is considering the need to require additional tests as supportive evidences for safety and efficacy of these products. Bioequivalence approaches such as in vitro release tests, in vitro skin permeation tests, dermatopharmacokinetic studies, and in vivo pharmacodynamic studies for corticosteroids, which are the most common therapeutic class of topical dermatological drug products in Brazil [7], may be included as requirements in the future.

In the continuous process of revising and updating regulatory recommendations, it is essential that international regulatory 
authorities and organizations share their experiences. Successful approaches implemented internationally could lead to a global alignment in regulatory requirements and would improve the efficacy of topically administered generic formulations.

\section{REFERENCES}

1. Braddy AC, Davit BM, Stier EM, Conner DP. Survey of international regulatory bioequivalence recommendations for approval of generic topical dermatological drug products. AAPS J. 2015;17(1):121-33.

2. Brazilian Health Surveillance Agency. 2006. Resolution RE $n^{\circ}$ 1170, 19 December 2006. Provides information about relative bioavailability/bioequivalence tests of medicines. http:// pesquisa.in.gov.br/imprensa/jsp/visualiza/ index.jsp?jornal $=1 \&$ pagina $=101 \&$ data $=24 / 04 / 2006$. Accessed 5 May 2015.

3. Brazilian Health Surveillance Agency. 2011. Resolution $n^{\circ} 37,03$ August 2011. Provides information about biowaiver and relative bioavailability/bioequivalence study substitution. http:// portal.anvis a.gov.br/w p s/w c m/connect/
1 c 626 d 0040 c b 51 e 6952 e b 51 b 0133649 b/ rdc0037_03_08_2011.pdf?MOD=AJPERES. Accessed 5 May 2015.

4. Brazilian Health Surveillance Agency. 2010. Resolution n`31, 11 August 2010. Provides information about pharmaceutical equivalence determination and dissolution profile comparison. http:// pesquisa.in.gov.br/imprensa/j sp/visualiza/ index.jsp?jornal $=1 \&$ pagina $=36 \&$ data $=12 / 08 / 2010$. Accessed 5 May 2015.

5. Brazilian Health Surveillance Agency. 2015. Public consultation $\mathrm{n}^{\circ}$ 18, 10 March 2015. http://portal.anvisa.gov.br/wps/content/ anvisa+portal/anvisa/regulacao+sanitaria/assuntos+de+interesse/ consultas + publicas/assuntos +de+interesse/ consultas+publicas+encerradas/2015/2015031118. Accessed 5 May 2015.

6. Brazilian Health Surveillance Agency. 2009. Resolution $\mathrm{n}^{\circ} 48,06$ October 2009. Provides information about alteration, inclusion, suspension, reactivation, cancelation post approval of medicines. http://portal.anvisa.gov.br/wps/wcm/connect/ 3 e 1 bf 0004515 f 86 a $82 \mathrm{fcf} 796514 \mathrm{~d} 51 \mathrm{c} 4$ $\mathrm{RDC}+\mathrm{N} \% \mathrm{C} 2 \% \mathrm{BA}+48 \% 2 \mathrm{C}+\mathrm{DE}+6+\mathrm{DE}+\mathrm{OUTUBRO}+\mathrm{D}-$ E+2009.pdf?MOD=AJPERES. Accessed 5 May 2015.

7. Soares KCC, Vogler M, Gelfuso GM, Gratieri T. Bioequivalence of dermatological topical medicines: the Brazilian scenario and the health surveillance challenges. Ciência e Saúde Coletiva. Accepted in February, 29th, 2015. 